\title{
Assessment of Microbial Properties of Pokkali Soil in Kerala, India
}

\author{
Beena S. George*, T.K. Ashique and N.K. Binitha \\ College of Agriculture, Padannakkad, Kerala Agricultural University, Kasaragod-671314, India \\ *Corresponding author
}

\begin{tabular}{|c|c|}
\hline & A B S T R A C T \\
\hline & $\begin{array}{l}\text { A study was conducted at College of Agriculture, Padannakkad to know the status of } \\
\text { various biological properties of Pokkali tracts. The parameters analysed were organic }\end{array}$ \\
\hline Keywords & $\begin{array}{l}\text { matter content, microbial biomass carbon, dehydrogenase activity and microbial } \\
\text { population comprising of bacteria, fungi and actinomycets. Thirty soil samples were }\end{array}$ \\
\hline $\begin{array}{l}\text { Pokkali, Biological } \\
\text { properties, Physico- } \\
\text { chemical properties. }\end{array}$ & $\begin{array}{l}\text { collected from different locations and analysed for the above said parameters using } \\
\text { standard procedures. The results revealed that the soil is rich in organic matter, which } \\
\text { ranged from } 2.04 \text { to } 3.57 \text { per cent. Microbial biomass carbon in the sample varied from }\end{array}$ \\
\hline Article Info & $\begin{array}{l}125.2 \text { to } 260.3 \mu \mathrm{g} \text { TPF } \mathrm{g}^{-1} \text { soil with a mean value of } 201.5 \mu \mathrm{g} \mathrm{TPF} \mathrm{g}^{-1} \text { soil. The } \\
\text { dehydrogenase activity in the soil was found to be between } 1985.48 \mu \mathrm{g} \mathrm{g}^{-1} \text { soil to } 2300 \mu \mathrm{g}\end{array}$ \\
\hline $\begin{array}{l}\text { Accepted: } \\
15 \text { October } 2017 \\
\text { Available Online: } \\
10 \text { December } 2017\end{array}$ & $\begin{array}{l}\mathrm{g}^{-1} \text {, which is comparatively higher than non-flooded soil, emphasizing that flooded } \\
\text { condition favours dehydrogenase activity. Bacterial, fungal and actinomycetes population } \\
\text { was } 4.3 \times 10^{7}, 2.3 \times 10^{4} \text { and } 3.2 \times 10^{4} \text { respectively. The presence study indicated that } \\
\text { flooded rice soil is one of the best sources to study microbial diversity. However detailed }\end{array}$ \\
\hline & $\begin{array}{l}\text { investigation is required to assess impact of microbial community on various soil } \\
\text { parameters. }\end{array}$ \\
\hline
\end{tabular}

\section{Introduction}

Pokkali tract named after a rice variety Pokkali, is a unique rice growing area scattered among Ernakulam, Thrissur and Alappuzha districts of Kerala. It extends over an area of 4000 hectares in Ernakulam district, 3000 hectares in Alappuzha district and 2000 hectares in Thrissur district. It is synonymous to Kaipad cultivation in Kannur and Kariland cultivation in Alappuzha. Pokkali tracts are low lying marshes located near the estuaries of rivers and are close to the sea. The rice cultivation is carried out during June to November, when the fields have low salinity due to flash flooding caused by south west monsoon shower. The salinity of the tract increases there after due to the inundation of sea water. Prawn cultivation is practiced during this high salinity phase. Farmers adopt a unique method of saline organic farming.

The major constraints regarding Pokkali land are high acidity and salinity, which delimits the cultivation of almost all the crops. Flooded rice is a suitable crop that can be grown in this location without much constraint. Other characteristics of Pokkali tracts include water-logging, poor drainage system and tidal action throughout the year. Since farmers in this tract are following strict organic method of cultivation, these soils are rich in organic matter, which may have great 
influence on biological properties of soil and have an impact on soil fertility. Another notable feature is the continuous submergence of the field, which will have a significant influence on native microorganisms. These all make the soil so unique and distinguishable from other soils of Kerala. The present study was conducted to know the status of microbial population and enzymatic activity of the Pokkali soil.

\section{Materials and Methods}

Thirty soil samples were collected from different locations of Pokkali tract and analysed for organic carbon, microbial biomass carbon (MBC) and dehydrogenase activity (DHA). Organic carbon (OC) of the soil was estimated by wet digestion method (Walkley and Black, 1934). The method proposed by Klien et al., (1971) was used to estimate dehydrogenase activity. The chloroform fumigation and extraction method was used to estimate microbial biomass carbon in soil.

\section{Results and Discussion}

Pokkali soils are classified as acid saline. The $\mathrm{pH}$ of the soil varied from 2.72 to 4.2. The soil is extremely acidic due to intermittent submergence and aeration. Aeration of the soil leads to oxidation of sulphides to sulphuric acid, which rapidly increases the soil acidity. Electrical conductivity of the soil was found to be very high with a mean value of $3.71 \mathrm{dSm}^{-1}$. Inundation of sea water might have contributed significant amount of soluble salts and hence increases the electrical conductivity. Pokkali soil is rich in organic matter and it ranged from 2.04 to 3.57 per cent, which is quite high and be attributed to addition of organic materials like FYM, compost and incorporation of straw and stubbles after harvest of rice besides maintaining moisture level at saturated condition. Microbial biomass carbon in the sample varied from 125.2 to $260.3 \mu \mathrm{g} \mathrm{g}^{-1}$ soil with a mean value of $201.5 \mu \mathrm{g} \mathrm{g}^{-1}$ soil.

Even though organic carbon content of the soil is high, it was not reflected in the microbial biomass carbon status, probably due to shift from aerobic to anaerobic situation in Pokkali soil. The dehydrogenase activity in the soil was found to be between $1985.48 \mu \mathrm{g} \mathrm{TPF} \mathrm{g}^{-1}$ and $2300 \mu \mathrm{g}$ TPF $\mathrm{g}^{-1}$ soil, which is comparatively higher than nonflooded soil, emphasizing that flooded condition favours dehydrogenase activity. Bacterial population was ranged between 2.8 x $10^{7}-4.8 \times 10^{7}$ with a mean value of $4.3 \times 10^{7}$ cfu. Even though the soil was very saline, remarkable activity of fungi was observed (Fig. 2).

Table.1 Various physico-chemical and biological properties of Pokali soil

\begin{tabular}{|l|l|l|}
\hline Parameter & Range & Mean value \\
\hline $\mathrm{pH}$ & $2.72-4.20$ & 3.64 \\
\hline $\mathrm{EC}\left(\mathrm{dSm}^{-1}\right)$ & $1.51-4.24$ & 3.71 \\
\hline $\mathrm{OC}(\%)$ & $2.04-3.57$ & 2.80 \\
\hline $\mathrm{MBC}\left(\mu \mathrm{g} \mathrm{g}^{-1}\right)$ & $125.2-260.3$ & 201.5 \\
\hline DHA $\left(\mu \mathrm{g} \mathrm{TPF} \mathrm{g}^{-1}\right)$ & $1985.48-2300$ & 2015.32 \\
\hline Bacteria & $2.8 \times 10^{7}-4.8 \times 10^{7}$ & $4.3 \times 10^{7}$ \\
\hline Fungi & $1.6 \times 10^{4}-3.2 \times 10^{4}$ & $2.3 \times 10^{4}$ \\
\hline Actinomycetes & $2.5 \times 10^{4}-4.1 \times 10^{4}$ & $3.2 \times 10^{4}$ \\
\hline
\end{tabular}


Fig.1 Microbial biomass carbon status in Pokkali soil

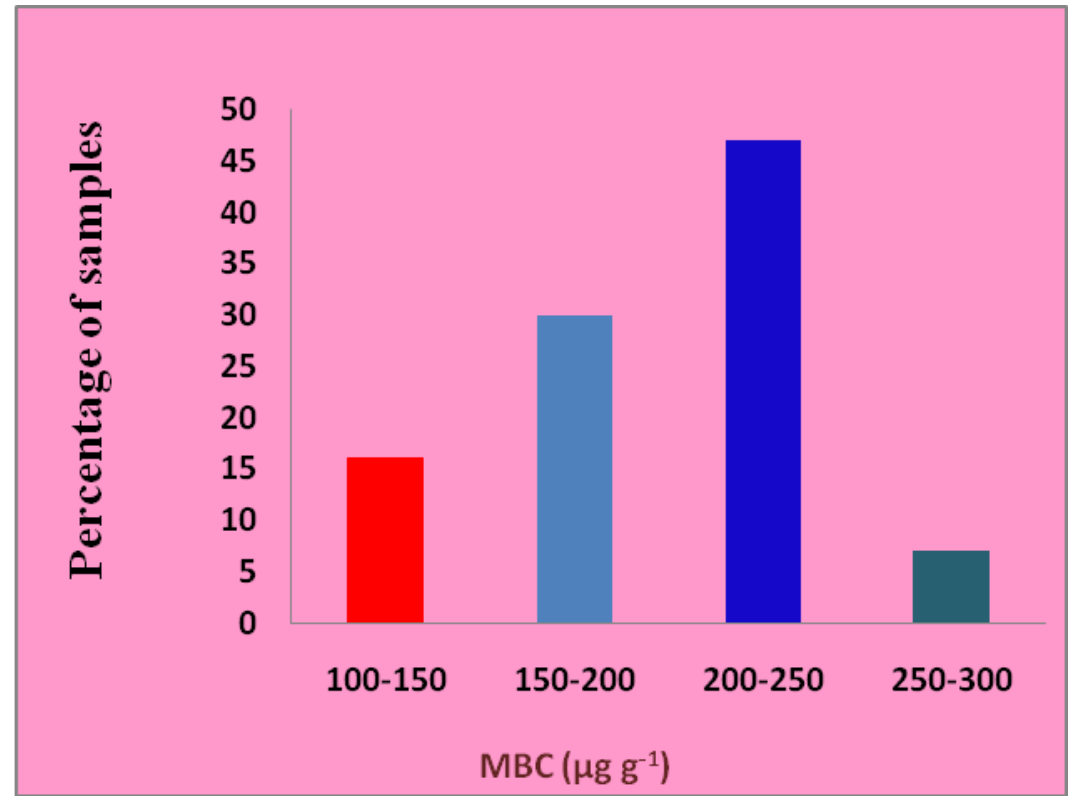

Fig.2 Dehydrogenase activity in Pokkali soil

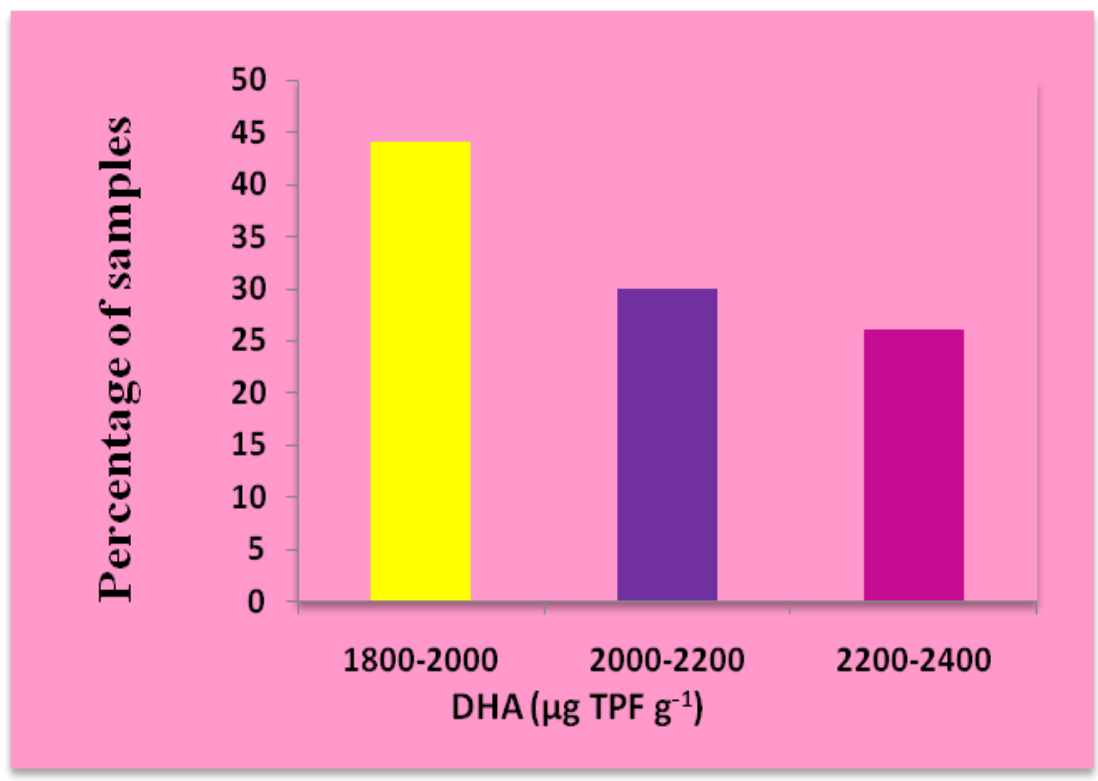

The population of fungi was positively correlated with organic matter of soil. Average population of fungi was $2.3 \times 10^{4}$ cfu. The mean value of actinomycetes population was $3.2 \times 10^{4} \mathrm{cfu}$ and it was higher than that of fungi, which clearly indicate actinomycetes can thrive well under stress condition (Table 1).
The presence study indicated that flooded rice soil is one of the best sources to study microbial diversity (Fig. 1).

Among flooded rice soils, Pokkali soils are distinguished from its high salinity and acidity. Pokkali soils with moderate to high content of organic matter can help in adjusting the soil $\mathrm{pH}$ to the neutral range, 
which benefits the wetland rice crop by favoring the nutrient uptake and improving the microbial community. This microbial community act as biocatalyst for the functioning of ecosystem and helps in nutrients transformation and decomposition of organic matter, thus improving fertility status of soil. However detailed investigation is required to assess impact of microbial community on various soil parameters.

\section{References}

Klien, D. A., Loh, T. C., and Goulding, R.L. 1971. A rapid procedure to evaluate the dehydrogenase activity of soils low in organic matter. Soil Biol. Biochem. 3, pp.385- 387.

Walkley, A.J. and Black, I.A. 1934. Estimation of soil organic carbon by chromic acid titration method. Soil Sci. 31, pp.29-38.

\section{How to cite this article:}

Beena S. George, T.K. Ashique and Binitha, N.K. 2017. Assessment of Microbial Properties of Pokkali Soil in Kerala, India. Int.J.Curr.Microbiol.App.Sci. 6(12): 1964-1967. doi: https://doi.org/10.20546/ijcmas.2017.612.224 